\title{
Pendidikan Muatan Lokal Sebagai Penanaman Karakter Cinta Tanah Air
}

\author{
Novi Nurdian ${ }^{1 *}$, Khalida Rozana Ulfah ${ }^{2}$, Rizki Nugerahani Ilise ${ }^{3}$
}

1,2,3 STKIP Islam Sabilal Muhtadin, Banjarmasin, Indonesia

\section{ART I C L E IN F O}

\section{Article history:}

Received June 09, 202

Revised June 15, 2021

Accepted July 03, 2021

Available online July 25, 2021

Kata Kunci:

Cinta Tanah Air, Muatan Lokal

Keywords:

Love For the Homeland, Local Content

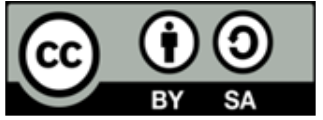

This is an open access article under the CC BY-SA license.

Copyright ( $(2021$ by Author. Published by Universitas Pendidikan Ganesha.

\begin{abstract}
A B S T R A K
Karakter cinta tanah air merupakan salah satu nilai dalam pendidikan karakter. Karakter cinta tanah air merupakan cara berpikir, bersikap, dan bertindak yang menunjukkan penghargaan terhadap tanah air. Untuk menanamkan karakter ini salah satunya dapat melalui mata pelajaran muatan lokal seni budaya Banjar. Tujuan penelitian ini yaitu mendeskripsikan peran dan dampak penanaman karakter cinta tanah air melalui mata pelajaran muatan lokal di Sekolah Dasar. Penelitian ini dilakukan di sekolah dasar menggunakan pendekatan penelitian kualitatif yakni jenis pendekatan kualitatif deskriptif. Data dikumpulkan dengan metode observasi dan wawancara. Setelah data terkumpul dilakukan proses pengkondingan data dan dilakukan pengecekan keabsahan data menggunakan uji kredibilitas dan konfirmabilitas. Hasil penelitian yang diperoleh yakni; Peran penanaman karakter cinta tanah melalui mata pelajaran muatan lokal seni budaya Banjar yakni dengan keteladanan makna seni budaya Banjar, pembelajaran, pemberdayaan dan pembudayaan, penguatan, dan penilaian. Dampak penanaman karakter cinta tanah air melalui mata pelajaran muatan lokal seni budaya Banjar adalah bertambah sikap dan perilaku melestarikan budaya Indonesia khususnya seni budaya Banjar. Nilai-nilai tersebut mengacu pada indikator karakter cinta tanah air pada siswa sekolah dasar. Dapat disimpulkan secara garis besar dampaknya siswa bertambah semangat untuk mempelajari seni budaya, tumbuh perasaan senang, peduli, dan bangga terhadap seni budaya Banjar.
\end{abstract}

\section{A B S T R A C T}

The character of love for the homeland is one of the values in character education. The character of love for the homeland is a way of thinking, behaving, and acting that shows respect for the homeland. To instill this character, one of them can be through local content subjects, Banjar arts and culture. The purpose of this study is to describe the role and impact of planting the character of love for the homeland through local content subjects in elementary schools. This research was conducted in elementary schools using a qualitative research approach, namely the type of descriptive qualitative approach. Data were collected by observation and interview methods. After the data is collected, the data conditioning process is carried out and the validity of the data is checked using credibility and confirmability tests. The research results obtained are; The role of planting the character of love for the land through local content subjects of Banjar art and culture, namely by exemplifying the meaning of Banjar culture, learning, empowerment and civilizing, strengthening, and assessment. The impact of planting the character of love for the homeland through local content subjects of Banjar art and culture is to increase attitudes and behaviors to preserve Indonesian culture, especially Banjar culture. These values refer to indicators of the character of love for the homeland in elementary school students. In general, it can be concluded that the impact of students is increasing enthusiasm for studying cultural arts, growing feelings of pleasure, care, and pride in Banjar arts and culture.

\section{PENDAHULUAN}

Karakter merupakan nilai-nilai perilaku individu yang saling berkaitan dengan Tuhan Yang Maha Esa, diri sendiri, sesama manusia, lingkungan, dan bangsa yang dimanifestasikan kedalam pikiran, sikap, perasaan, perkataan, dan tindakan berdasarkan norma agama, hukum, tata krama, budaya, dan adat istiadat. Karakter yang baik tentu menjadi hal yang wajib dimiliki oleh setiap individu sebagai modal awal dalam menjalani kehidupan sosial (Basri \& Dwiningrum, 2020; Santika, 2020). Karakter dibentuk dari tiga macam bagian yang berkaitan antara lain pengetahuan moral, perasaan moral, dan perilaku moral (Marwa \& Kamalia, 2019). Karakter diibarat 
seperti otot yang sudah terbentuk dan berkembang melalui proses yang panjang dari latihan juga kedisiplinan yang dilakukan setiap hari hingga kokoh dan kuat. Seseorang bisa dikatakan memiliki karakter baik jika dia mampu menunjukan nilai positif yang ada pada dirinya sehingga terlihat serta dirasakan oleh orang disekitarnya, seperti jujur, bertanggung jawab, disiplin, dapat bekerjasama, toleransi dan lain sebagainya (Fauzi et al., 2017). Selain itu seseorang dapat dikatakan berkarakter kurang baik jika memperlihatkan nilai-nilai negatif didirinya yang dirasakan oleh orang lain seperti suka membuat keributan, mencuri, membunuh, membuli dan lain sebagianya (Puspitasari \& Herdiati, 2020). Salah satu karakter yang diperlukan serta dapat di lakukan pada siswa adalah karakter cinta tanah air. Karakter cinta tanah air merupakan upaya sepenuh hati menerima tanah tumpah darah negara sebagai bagian yang wajib kita lindungi serta kita kembangkan (Miranda, 2019). Cinta tanah air dapat diartikan juga cara berpikir, bersikap, dan berbuat yang menunjukan kesetiaan, kepedulian, dan penghargaan yang tinggi terhadap bahasa, lingkungan fisik, sosial, budaya, ekonomi, dan politik bangsa (Arif, 2018; H, 2017). Rasa cinta tanah air harus ditanamkan kepada anak sejak dini agar sebagai generasi penerus bangsa dapat mewujudkan sikap dan tingkah laku yang bermanfaat bagi kepentingan masyarakat dan menghindari penyimpangan-penyimpangan sosial yang bisa merusak norma dan nilai kebudayaan Indonesia. Penanaman karakter cinta tanah air dilakukan, mengingat bahwa bangsa ini membutuhkan generasi yang lebih baik di masa yang akan datang. Menanamkan karakter cinta tanah air dapat diawali dengan mengenal, memahami, serta menghargai budaya lokal yang ada di lingkungan sekitar.

Karena nilai-nilai kebudayaan bangsa inilah yang mencerminkan kecintaan kita terhadap bangsa dan negara. Namun dari karakter yang diharapkan masih belum mampu diterapkan secara maksimal oleh siswa. Yang berdapak terhadap sikap Adanya gelombang globalisasi yang begitu besar menjadikan kemerosotan moral dan lunturnya karakter yang dimilki oleh warga Negara (Arif, 2018). Rasa cinta tanah air siswa masih rendah (Mahilda \& Wihaskoro, 2018). Hal ini tentunya berdapak terhadap Permasalahan karakter yang terjadi saat ini antara lain sering terjadinya tawuran antar pelajar, kurang menghargai akan seseorang yang lebih tua, pencurian, terjadinya pembunuhan dengan faktor pemicu yang dapat dianggap sepele, serta maraknya terjadi pembullian antar sesama siswa di sekolah, dan masih banyak lagi permasalahan karakter yang terjadi. Hal-hal tersebut merupakan sikap yang tidak mencerminkan karakter yang diharapkan, dimana disebutkan kemendiknas (2010:9-10) nilai-nilai karakter yang di kembangkan di sekolah ialah sikap religius (melaksanakan ajaran agama), jujur, toleransi (menghargai), disiplin (tertib), kerja keras (bersungguh-sungguh), kreatif, mandiri (tidak tergantung pada orang lain), demokratis, rasa ingin tahu, semangat kebangsaan, cinta tanah air (nasionalisme), menghargai prestasi, bersahabat, cinta damai, gemar membaca, peduli lingkungan, peduli sosial, dan tanggung jawab (Ainurrosidah et al., 2018).

Berbagai permasalahan karakter yang terjadi maka solusi yang di berikan yakni sebuah pembelajaran karakter berbasis kebudayaan lokal. Salah satu strategi yang dapat digunakan dalam membentuk karakter bangsa adalah pengembangan kurikulum muatan lokal (MULOK) yang sudah dilakukan sejak lama dalam pendidikan di Indonesia. Pengembangan MULOK merupakan pengembangan konsep pendidikan yang sesuai dengan konsep dari Ki Hajar Dewantara yaitu Trikon. Teori Trikon, ialah kontinuitas berarti bahwa garis hidup sekarang harus merupakan lanjutan dari kehidupan pada zaman lampau berikut penguasaan unsur tiruan dari kehidupan dan kebudayaan bangsa lain; konvergensi berarti harus menghindari hidup menyendiri, terisolasi dan mampu menuju ke arah pertemuan antar bangsa dan komunikasi antar negara menuju kemakmuran bersama atas dasar saling menghormati, persamaan hak, dan kemerdekaan masing-masing; dan konsentris berarti setelah bersatu dan berkomunikasi dengan bangsa-bangsa lain di dunia, jangan kehilangan kepribadian sendiri. Pelaksanaan pembelajaran muatan lokal selain dimaksudkan untuk mempertahankan kelestarian (berkenaan dengan kebudayaan daerah), juga perlu ditujukan pada usaha pembaharuan atau modernisasi (berkenaan dengan keterampilan atau kejuruan lokal sesuai dengan perkembangan ilmu dan teknologi modern) (Faisal \& Sulkipani, 2016; Segoro et al., 2019). Pelaksanaan muatan lokal juga bermaksud agar pengembangan sumber daya manusia yang terdapat di daerah setempat dapat dimanfaatkan untuk kepentingan pembangunan daerah, sekaligus untuk mencegah terjadinya depopulasi daerah itu dari tenaga produktif. Secara umum, program pendidikan muatan lokal adalah mempersiapkan murid agar mereka memiliki wawasan yang mantap tentang lingkungannya serta sikap dan perilaku bersedia melestarikan dan mengembangkan sumber daya alam, kualitas sosial, dan kebudayaan yang mendukung pembangunan nasional maupun pembangunan setempat (Mahfudlo et al., 2019; Muktadir, 2018).

Melalui pendidikan karakter berbasis kebudayaan lokal yang diterapkan di sekolah, peserta didik dapat meningkatkan kecintaannya terhadap budaya daerahnya dan menanamkan nilai sosio kultural yang melingkupi peserta didik (Nafisah, 2016b; Wicaksono et al., 2018). Pemahaman nilai karakteristik daerah kepada peserta didik diharapkan dapat membentuk karaktek peserta didik. Dengan begitu peserta didik akan menjadikan arus global menjadi tambahan kekayaan nilai sosio kultural tanpa menghilangkan nilai budaya daerah. Muatan lokal diberikan dalam rangka usaha pengenalan pemahaman dan pewarisan nilai karakteristik daerah kepada peserta didik (Arifin et al., 2018; Sundari et al., 2018). Kedudukan muatan lokal bukanlah mata pelajaran yang berdiri sendiri, tetapi merupakan mata pelajaran terpadu, yaitu bagian dari mata pelajaran yang sudah ada. Dalam pendidikan karakter juga memiliki tujuan yakni menguatkan dan mengembangkan nilai-nilai kehidupan yang 
dianggap penting dan perlu sehingga menjadi kepribadian atau kepemilikan peserta didik yang khas sebagaimana nilai-nilai yang dikembangkan. Kemudian mengoreksi perilaku peserta didik yang tidak bersesuaian dengan nilai-nilai yang dikembangkan oleh sekolah. Serta membangun koneksi yang harmonis dengan keluarga dan masyarakat dalam memerankan tanggung jawab pendidikan karakter secara umum (Amaliah, 2016). Oleh karena itu, penanaman pendidikan karakter tidak bisa hanya sekadar mentransfer ilmu pengetahuan atau melatih suatu keterampilan tertentu. Penanaman pendidikan karakter perlu rangkain proses berupa teladan, pembiasaan atau pembudayaan, dan penguatandalam lingkungan peserta didik baik dalam lingkungan sekolah, keluarga, lingkungan masyarakat, maupun lingkungan (exposure) media masa. Pencapaian misi pendidikan karakter diperlukan harmoni yang selaras dari segenap unsur lingkungan agar tercapai sinergi.

Dari beberapa penelitian relevan pada tahap pembentukan karakter melalui tiga tahap yaitu, tahap pembentukan, pengembangan dan pemantapan yang disesuaikan berdasarkan jenjangnya, karakter utama yang dibentuk yaitu, karakter kedisiplinan, cinta tanah air dan bangsa, tanggon, tangguh, trengginas, mandiri, unggul, religius, sehingga pada saat menyelesaikan sebuah permasalahan siswa saling bekerjasama dan berkoordinasi dalam menyelesaikannya (Danti et al., 2019). Karakter dalam membentuk sikap dan perilaku sosial siswa di lakukan agar menjadi kebiasaan sehingga nilai-nilai karakter yang nantinya dapat membentuk sikap dan perilaku sosial siswa. Setelah penerapan pembelajaran karakter cinta tanah air sikap serta perilaku sosial siswa dapat dikatakan sudah baik (Utomo \& Muntholib, 2018). Dalam pelaksanaan pembelajaran karakter cinta tanah air, sikap dan tindakan siswa telah mencerminkan nilai-nilai dair pada pendidikan karakter (Khoirina et al., 2017). Pembelajaran karakter berbasis cinta tanah air, orang tua dan guru juga bekerja sama dalam mengajarkan pendidikan karakter dan moral untuk siswa (Birhan et al., 2021). Dengan demikian siswa menjadi lebih cinta tanah air sehingga karakter-karakter yang di harapkan dapat tercapai (Torimtubun et al., 2020). Agar kecintaan terhadap tanah air tak tergerus dengan perkembangan zaman yang semakin modern, dengan begitu penanaman karakter cinta tanah air dapat diperoleh dari pembelajaran muatan lokal yang dapat diterapkan sejak tingkat sekolah dasar, adapun tujuan dari penelitian ini yakni untuk mengetahui bagaimana peran dan dampak pembelajaran muatan lokal sebagai penanaman karakter cinta tanah air.

\section{METODE}

Penelitian yang akan dilaksanakan menggunakan jenis penelitian diskriptif kualitatif yang diarahkan kepada studi naratif. Analisis naratif merupakan istilah umum yang menangkap informasi dari dimensi pribadi, dan pengalaman manusia dari waktu ke waktu, dan memperhitungkan hubungan antara pengalaman individu dan konteks budaya (John MC, 2001). Peneliti menggunakan desain penelitian kualitatif deskriptif sehubungan dengan data-data yang hendak peneliti gali yang akan dianalisis dengan menghasilkan data deskriptif yakni berupa kata-kata sebagai pendeskripsian terhadap fakta-fakta tertentu. Penelitian ini dilaksanakan untuk mengidentifikasi pendidikan muatan lokal sebagai penanaman karakter cinta tanah air. Dalam penilitian ini yang menjadi partisipan penelitian adalah kepala sekolah dan 2 guru pengampu mata pelajaran pendindikan Muatan Lokal di SDN Melayu 2 Banjarmasin. Subyek penelitian berfokus pada guru mata pelajaran muatan lokal seni budaya. Sementara alat dan sumber data sekunder dalam penelitian ini yakni berupa dokumen-dokumen yang mendukung penelitian seperti profil sekolah, jadwal mata pelajaran muatan lokal seni budaya, daftar presensi, daftar nilai, daftar perolehan prestasi seni dan sebagainya. Penelitian ini bertujuan untuk mengetahui bagaimana peran dan dampak pembelajaran kurikulum muatan lokal sebagai penanaman karakter cinta tanah air.

Pengumpulan data dilakukan dengan studi wawancara dan studi dokumentasi. Instrumen studi wawancara berisikan pertanyaan-pertanyaan mengenai penerapan pendidikan karakter di sekolah dasar, peran pendidikan karakter dalam muatan lokal seni budaya, penanaman karakter cinta tanah air dalam pembelajaran muatan lokal, dan dampak penanaman karakter cinta tanah air melalui mata pelajaran muatan lokal seni budaya. Untuk data kualitatif langkah-langkah analisisnya sebagai berikut. Peneliti membuat catatan lapangan yang dapat digunakan dalam pengumpul data. Format yang disiapkan memuat variabel dan indikator kajian sehingga catatan lapangan terarah dan tidak menyimpang dari tujuan kajian. Setelah membuat catatan lapangan dilanjutkan dengan pemetaan terhadap jawaban responden pada setiap pertanyaan kajian untuk mengetahui apakah ada jawaban yang sama atau bertentangan dan sebagainya. Jika ada jawaban yang bertentangan maka dibuat narasi atau alasan yang memungkinkan mengakibatkan terjadi jawaban yang bertentangan. Dari pemetaan jawaban responden tersebut ditarik simpulan yang bisa menjawab tujuan kajian. Analisis data yang peneliti lakukan menggunakan analisis deskriptif yakni data-data yang telah terkumpul baik primer dan sekunder diolah kemudian dianalisis dan dibandingkan dengan teori yang telah dibahas kemudian disimpulkan. 


\section{HASIL DAN PEMBAHASAN}

\section{Hasil}

Dari studi dokumentasi yang dilakukan, didapatkan hasil penerapan muatan muatan lokal di SDN Melayu 2 Banjarmasin. Sesuai dengan Perda Prov Kalsel nomor 3 tahun 2010 tentang Pendidikan, pada pasal 26 ayat 1 menyebutkan bahwa Kurikulum pendidikan dasar dan menengah wajib memuat salah satunya yakni mata pelajaran muatan lokal. Materi muatan lokal sebagaimana dimaksud pada ayat (1) huruf j (muatan lokal) adalah materi muatan yang berbasis keunggulan lokal terdiri atas 2 (dua) macam, yaitu bersifat wajib dan bersifat pilihan. Materi muatan berbasis keunggulan lokal bersifat wajib yaitu pendidikan Al-Qur'an bagi peserta didik yang beragama Islam dan pembelajaran budi pekerti. Materi muatan berbasis keunggulan lokal bersifat pilihan yaitu bahasa daerah banjar, kesenian dan budaya daerah banjar dan keterampilan berbasis potensi alam. Maka SDN Melayu 2 Banjarmasin menerapkan muatan lokal Seni Budaya Banjar sebagai mata pelajaran muatan lokal utama di pembelajaran sekolah. Hasil dari studi wawancara terhadap kepala sekolah dan guru muatan lokal seni budaya ditemukan adanya peran-peran yang dapat membentuk karakter cinta tanah air melalui pembelajaran muatan lokal seni budaya Banjar, Peran pendekatan penanaman karakter cinta tanah air melalui mata pelajaran muatan lokal di SDN Melayu 2 Banjarmasin berdasarkan data di lapangan yakni keteladanan dalam mengembangkan seni budaya Banjar. Kemudian pembelajaran dari pemilihan strategi, model, dan metode. Pemberdayaan dan pembudayaan. Kemudian penguatan dengan menyisipkan nilai-nilai dalam pembelajaran dan memberi penghargaan dan penilaian melalui observasi keaktifan siswa, rekap daftar absensi, dan analisis hasil kerja siswa. Sasaran penanaman karakter cinta tanah air melalui pembelajaran seni budaya Banjar yakni peserta didik. Kegiatan pembelajaran tersebut secara langsung maupun tidak langsung berdampak pada karakter peserta didik, salah satunya karakter cinta tanah air. Dampak penanaman karakter cinta tanah air melalui pembelajaran muatan lokal seni budaya Banjar bagi siswa di SDN Melayu 2 Banjarmasin ditunjukkan dengan sikap dan perilaku melestarikan budaya Indonesia khususnya seni budaya Banjar. Lebih jelasnya dampak penanaman kakarter cinta tanah air bagi siswa yakni; (1) Bertambah semangat untuk mempelajari seni budaya Banjar, (2) Tumbuh perasaan senang siswa terhadap seni budaya Banjar, (3) Tumbuh kepedulian siswa terhadap seni budaya Banjar dan (4) Tumbuh perasaan bangga siswa terhadap seni budaya Banjar.

Hasil penelitian menunjukkan dalam rangka penanaman karakter maka dilakukan beberapa pendekatan yang berperan untuk menumbuhkan karakter cinta tanah air yakni keteladanan, pembelajaran, penguatan, pemberdayaan dan pembudayaan, serta penilaian. Sebagaimana dalam desain induk pendidikan karakter Kemdiknas memaparkan ada 6 pendekatan dalam pendidikan karakter yakni keteladanan, pembelajaran, pemberdayaan dan pembudayaan, dan penguatan. Teori tersebut berkaitan dengan data temuan peneliti mengenai peran pendekatan penanaman karakter cinta tanah air melalui mata pelajaran muatan lokal seni budaya Banjar di SDN Melayu 2 Banjarmasin. Berikut analisis beserta penjelasannya: Pertama, keteladanan, salah satu keteladanan yang patut dicontoh dari seni budaya Banjar ialah nilai-nilai Islam yang terkandung dalam beberapa seni budaya ada Banjar yang telah diciptakan nenek moyang. Beberapa seni budaya Banjar diciptakan untuk menyampaikan pesan-pesan islami untuk warga atau rakyat Banjar. Salah satunya ialah kesenian madihin dimana didalamnya terkandung pesan moral yang bersifat islami namun tetap menghibur. Keteladanan dalam menyampaikan pesan kebaikan inilah yang harus dilestarikan dan dikembangkan. Menyampaikan pesan positif melalui hiburan agar mudah diterima oleh masyarakat diberbagai kalangan. Kedua, Pemberdayaan dan pembudayaan, dalam pemberdayaan dan pembudayaan mata pelajaran muatan lokal seni budaya Banjar, didalamnya ditemukan adanya intervensi dan habituasi sehubungan dengan penanaman karakter cinta tanah air. Guru membimbing dan mengarahkan siswa dengan mentransfer ilmu baik teori dan praktik. Selama praktik sang guru senantiasa memberi contoh terlebih dahulu. Sementara dalam membentuk habituasi siswa berlatih praktek dalam banyak pertemuan. Sebagaimana dalam pembelajaran ini siswa ditargetkan menghasilkan berbagai karya seni budaya Banjar dimana tingkat kesulitan disesuaikan dengan jenjang kelas peserta didik. Proses pembelajaran praktik yang diajarkan pada siswa secara berulang merupakan bagian dari habituasi.

Ketiga, Penguatan Terdapat peran penguatan terkait dengan penanaman nilai-nilai karakter cinta tanah air yang peneliti temukan dalam pembelajaran muatan lokal Seni Budaya Banjar di SDN Melayu 2 Banjarmasin. Guru melakukan penegasan pentingnya karakter cinta tanah air yang disisipkan dalam proses pembelajaran. Sebagai contoh sang guru mengisahkan sejarah budaya Banjar dan memotivasi siswa untuk melestarikan kesenian dan budaya Banjar sebelum praktik pembelajaran dilakukan peserta didik. Penampilan siswa siswi terbaik akan dipilih menjadi wakil sekolah untuk ajang perlombaan ditingkat daerah maupun nasional sebagai bentuk penguatan sekaligus penghargaan terhadap siswa siswi yang berbakat dalam mempraktikkan seni budaya Banjar. Keempat, penilaian Pengajar seni budaya Banjar melakukan penilaian terhadap pencapaian nilai-nilai budaya dan karakter peserta didik. Penilaian yang dimaksud tidak sebatas kognitif siswa namun juga terkait pencapaian nilai-nilai karakternya. Penilaian karakter tersebut didasarkan pada beberapa indikator. Pada penilaian karakter cinta tanah air terdapat beberapa indikator seperti senang mempraktikkan seni budaya Banjar, kagum, peduli, dan bangga terhadap seni budaya Banjar, serta semangat melestarikannya. Tercapai tidaknya nilai-nilai tersebut bisa diketahui melalui observasi dan analisis hasil kerja siswa. Contohnya senang 
tidaknya siswa terhadap seni budaya Banjar dapat dilihat dari keaktivan selama mengikuti pembelajaran, absensi kehadiran siswa, dan hasil praktik siswa. Apabila siswa aktif, kehadiran siswa konsisten, dan hasil praktiknya semakin membaik hal tersebut menunjukkan antusiasme yang tinggi dalam mengikuti pembelajaran seni budaya Banjar.

Adapun data temuan peneliti dan pemaparan teori yang telah peneliti bahas sebelumnya. Maka dampak penanaman kakarter cinta tanah air melalui pembelajaran seni budaya di SDN Melayu 2 Banjarmasin yakni berupa pelestarian budaya yang dapat dijabarkan sebagai berikut:1) Siswa bertambah semangat untuk mempelajari seni budaya Banjar; 2) Antusiasme mereka ditunjukkan dengan tingkat kehadiran yang tinggi; 3) Tumbuh perasaan senang siswa terhadap seni budaya Banjar Mempelajari seni dan budaya Banjar tidaklah mudah meski sering dijumpai dikeseharian, sebab membutuhkan kecermatan, ketelitian, dan kesabaran dalam mempraktikkannya; 4) Tumbuh kepedulian siswa terhadap seni budaya Banjar Penanaman karakter cinta tanah air pada pembelajaran seni budaya Banjar menumbuhkan kepedulian siswa terhadap seni khas daerah yang harus dilestarikan. 5) Tumbuh perasaan bangga siswa terhadap seni budaya Banjar, Seni budaya Banjar sudah merambah ke luar daerah Kalimantan Selatan. Dari jabaran ini dapat dikatakan bahwa adanya pendidikan berbasis muatan lokal akan memberikan dampak terhadap kerakter cinta tanah air. Karakter cinta tanah air merupakan upaya sepenuh hati menerima tanah tumpah darah negara sebagai bagian yang wajib kita lindungi serta kita kembangkan (Miranda, 2019). Cinta tanah air dapat diartikan juga cara berpikir, bersikap, dan berbuat yang menunjukan kesetiaan, kepedulian, dan penghargaan yang tinggi terhadap bahasa, lingkungan fisik, sosial, budaya, ekonomi, dan politik bangsa (Arif, 2018; H, 2017). Rasa cinta tanah air harus ditanamkan kepada anak sejak dini agar sebagai generasi penerus bangsa dapat mewujudkan sikap dan tingkah laku yang bermanfaat bagi kepentingan masyarakat dan menghindari penyimpangan-penyimpangan sosial yang bisa merusak norma dan nilai kebudayaan Indonesia. Penanaman karakter cinta tanah air dilakukan, mengingat bahwa bangsa ini membutuhkan generasi yang lebih baik di masa yang akan dating. Adanya pendidikan Muatan local akan membuat siswa lebih menganal budayanya.

Pelaksanaan pembelajaran muatan lokal selain dimaksudkan untuk mempertahankan kelestarian (berkenaan dengan kebudayaan daerah), juga perlu ditujukan pada usaha pembaharuan atau modernisasi (berkenaan dengan keterampilan atau kejuruan lokal sesuai dengan perkembangan ilmu dan teknologi modern) (Faisal \& Sulkipani, 2016). Pelaksanaan muatan lokal juga bermaksud agar pengembangan sumber daya manusia yang terdapat di daerah setempat dapat dimanfaatkan untuk kepentingan pembangunan daerah, sekaligus untuk mencegah terjadinya depopulasi daerah itu dari tenaga produktif. Secara umum, program pendidikan muatan lokal adalah mempersiapkan murid agar mereka memiliki wawasan yang mantap tentang lingkungannya serta sikap dan perilaku bersedia melestarikan dan mengembangkan sumber daya alam, kualitas sosial, dan kebudayaan yang mendukung pembangunan nasional maupun pembangunan setempat. pendidikan muatan lokal, membantu terwujudnya program pendidikan yang tepat, efektif, efisien dan pengembangan karakter peserta didik (Syaifuddin \& Fahyuni, 2019). Pembangunan karakter bangsa perlu diperhatikan demi terwujudnya masyarakat Indonesia yang aman, bermartabat dan sejahtera, maka masih banyak persoalan yang diteliti, sehingga dapat diambil langkah yang positif. Bagi peneliti berikutnya disarankan hendaknya lebih mendalami terkait penanaman karakter cinta tanah air melalui muatan lokal sebab masih banyak unsur-unsur yang belum terpaparkan secara rinci pada penelitian ini dengan kajian lebih mendalam.

Penelitian ini sejalan dengan implementasi kurikulum muatan lokal bahasa Using sangat berperan dalam upaya pembentukan karakter siswa di SMPN 1 Giri. Kurikulum muatan lokal bahasa Using memiliki penekanan pada wawasan dan pengembangan ilmu pengetahuan, tetapi juga menekankan pada pembentukan dan pembinaan karakter siswa melalui penguatan terhadap nilai-nilai kebudayaan hasil warisan leluhur. Jadi dapat disimpulkan penelitian ini dapat membentuk peserta didik yang dapat menguasai kebudayaan dan bahasa Using secara mendalam dan merupakan landasan dasar dalam membangun kehidupan manusia yang berkarakter luhur (Nafisah, 2016a). Selain itu tentang membangun karakter siswa melalui pembelajaran batik di sekolah mengatakan bahwa Pembelajaran batik merupakan pelaksanaan pendidikan seni di sekolah diberikan karena keunikan, kebermaknaan dan kebermanfaatan terhadap kebutuhan perkembangan peserta didik, yang terletak pada pemberian pengalaman estetik dalam bentuk kegiatan berekspresi/berkreasi dan berapresiasi. Pengalaman estetik yang diberikan pada pembelajaran batik pada prinsipnya berfungsi melatih dan mengembangkan kepekaan rasa. Dengan kepekaan rasa yang tinggi mental seseorang cenderung mudah diisi dengan nilai-nilai hidup dan kehidupan, seperti nilai religius, nilai moral, nilai budi pekerti (melatih disiplin, teliti, sabar, bersih, dll) (Sulfahri, 2018). Pembentukan karakter melalui tiga tahap yaitu, tahap pembentukan, pengembangan dan pemantapan yang disesuaikan berdasarkan jenjangnya, karakter utama yang dibentuk yaitu, karakter kedisiplinan, cinta tanah air dan bangsa, tanggon, tangguh, trengginas, mandiri, unggul, religius, sehingga pada saat menyelesaikan sebuah permasalahan siswa saling bekerjasama dan berkoordinasi dalam menyelesaikannya (Danti et al., 2019). Karakter dalam membentuk sikap dan perilaku sosial siswa di lakukan agar menjadi kebiasaan sehingga nilai-nilai karakter yang nantinya dapat membentuk sikap dan perilaku sosial siswa. Setelah penerapan pembelajaran karakter cinta tanah air sikap serta perilaku sosial siswa dapat dikatakan sudah baik (Utomo \& Muntholib, 2018). Dalam pelaksanaan pembelajaran karakter cinta tanah air, sikap dan 
tindakan siswa telah mencerminkan nilai-nilai dair pada pendidikan karakter (Khoirina et al., 2017). Pembelajaran karakter berbasis cinta tanah air, orang tua dan guru juga bekerja sama dalam mengajarkan pendidikan karakter dan moral untuk siswa (Birhan et al., 2021). Dengan demikian siswa menjadi lebih cinta tanah air sehingga karakter-karakter yang di harapkan dapat tercapai (Torimtubun et al., 2020). Dengan demikian membangun karakter siswa dengan pembelajaran batik dapat dilaksanakan melalui kegiatan sekolah dan proses pembelajaran di kelas, sehingga pembelajaran batik di sekolah dapat sebagai sarana membangun karakter siswa untuk membentuk insan yang berkualitas.

\section{SIMPULAN}

Muatan lokal dapat menumbuhkan kecintaan peserta didik sebagai penerus bangsa akan nilai-nilai sosio kultural daerahnya dan negerinya. Selain itu nilai moral yang terkandung pada setiap daerah dapat ditumbuhkan dalam diri peserta didik maupun pendidik. Sehingga terwujudlah karakter bangsa sesuai dengan budaya lokal. Penelitian ini akan membantu terwujudnya program pendidikan yang tepat, efektif, efisien dan pengembangan karakter peserta didik. Pembangunan karakter bangsa perlu diperhatikan demi terwujudnya masyarakat Indonesia yang aman, bermartabat dan sejahtera, maka masih banyak persoalan yang diteliti, sehingga dapat diambil langkah yang positif.

\section{DAFTAR PUSTAKA}

Ainurrosidah, L., Ulfatin, N. \& Wiyono, B. B. (2018). Pembentukan Karakter Peserta Didik Pada Sekolah Berbasis Pesantren Melalui Implementasi Kurikulum Terpadu. Jurnal Administrasi Dan Manajemen Pendidikan, 1(2), 160-170. https://doi.org/10.17977/um027v1i22018p160.

Amaliah, D. (2016). Pengembangan Muatan Lokal Sebagai Salah Satu Strategi Menghadapi Masyarakat Eekonomi Asean (MEA). Jurnal Pendidikan 23. https://d1wqtxts1xzle7.cloudfront.net/53522012/Prosiding_4_Pendidikan-with-cover-page-v2.pdf?.

Arif, M. (2018). Revitalisasi Pendidikan Cinta Tanah Air di Pondok Pesantren Darul Ihsan Meganti Gresik. Jurnal Iqra: Kajian Ilmu Pendidikan, 3(2), 277-296. https://doi.org/10.25217/ji.v3i2.369.

Arifin, M. Z., Ulfa, S. \& Praherdhiono, H. (2018). Pengembangan kurikulum muatan lokal karawitan sebagai upaya mengkonstruksi pengetahuan dan pelestarian budaya jawa di jenjang sma. Jurnal Kajian Teknologi Pendidikan, 1, 2-10. http://journal2.um.ac.id/index.php/jktp/article/view/3707.

Basri, B. \& Dwiningrum, N. R. (2020). Peran Ormawa dalam Membentuk Nilai-nilai Karakter di Dunia Industri (Studi Organisasi Kemahasiswaan di Politeknik Negeri Balikpapan). Al-Adabiya: Jurnal Kebudayaan Dan Keagamaan, 15(01), 139-160. https://doi.org/10.37680/adabiya.v15i01.273.

Birhan, W., Shiferaw, G., Amsalu, A., Tamiru, M. \& Tiruye, H. (2021). Exploring the context of teaching character education to children in preprimary and primary schools. Social Sciences \& Humanities Open, 4(1), 100171. https://doi.org/10.1016/j.ssaho.2021.100171.

Danti, N. R., Benty, D. D. N. \& Nurabadi, A. (2019). Sistem Pengasuhan Dalam Kurikulum Khusus Sebagai Pembentukan Karakter Di Sma Berbasis Ketarunaan. Jurnal Administrasi Dan Manajemen Pendidikan, 2(4), 232-237. https://doi.org/10.17977/um027v2i42019p232.

Faisal, E. El \& Sulkipani, S. (2016). Pengembangan bahan ajar berbasis muatan lokal pada mata kuliah Pendidikan Kewarganegaraan. Jurnal Civics: Media Kajian Kewarganegaraan, 13(2), 113-126. https://doi.org/10.21831/civics.v13i2.12721.

Fauzi, H. A., Komalasari, K. \& Malik, Y. (2017). Utilization of Audio-Visual Media to Improve Student Learning Result in IPS Learning. International Journal Pedagogy of Social Studies, 2(1), 88-103. https://doi.org/https://doi.org/10.17509/ijposs.v2i1.8666.

H, A. W. (2017). Penerapan Media Video Jejak Petualang Trans 7 Dalam Pembelajaran Ilmu Pengetahuan Sosial (IPS) untuk Meningkatkan Karakter Cinta Tanah Air pada Siswa Kelas VIII G SMP Negeri 3 Lembang. International Journal Pedagogy of Social Studies, $1(1), \quad 88-99$. https://doi.org/10.17509/ijposs.v1i1.2086.

Khoirina, I., Suyitno, S. \& Winarni, R. (2017). Character Educational Value of Kalamata Novel By Ni Made Purnama Sari and Its Relevance for Teaching Literature in High School. Lingua Didaktika: Jurnal Bahasa Dan Pembelajaran Bahasa, 11(2), 123. https://doi.org/10.24036/ld.v11i2.7944.

Mahfudlo, M., Sulton, S. \& Ulfa, S. (2019). Pengembangan Kurikulum Muatan Lokal Seni Ukir Jepara Sebagai Upaya Kelestarian. Jurnal Kajian Teknologi Pendidikan, 2(3), 238-244. https://doi.org/10.17977/um038v2i32019p238.

Mahilda, D. K. \& Wihaskoro, A. M. (2018). Multimedia Interaktif Bermuatan Keanekaragaman Budaya Indonesia pada Pembelajaran Tematik untuk Meningkatkan Rasa Cinta Tanah Air Siswa Sekolah Dasar. Elementary School, 5(1), 130-138. https://doi.org/10.31316/esjurnal.v5i1.606.

Marwa, A. \& Kamalia, N. (2019). Representasi Pendidikan Karakter Di Film Dua Garis Biru Berdasarkan 
Perspektif Thomas Lickona. Prosiding Konferensi Pendidikan Nasional, 32-41.

Miranda, D. (2019). Pengembangan Video Animasi Berbasis Karakter Cinta Tanah Air Untuk Anak Usia Dini. Jurnal Visi Ilmu Pendidikan, 11(2), 12. https://doi.org/10.26418/jvip.v11i2.32565.

Muktadir, A. (2018). Model Bahan Ajar Mulok Berbasis Cerita Rakyat untuk Pendidikan Karakter Di SD. Litera, 17(1), 135-142. https://doi.org/10.21831/ltr.v17i1.19128.

Nafisah, D. (2016a). Peran pendidikan muatan lokal terhadap pembangunan karakter bangsa. CITIZENSHIP: Jurnal Pancasila Dan Kewarganegaraan, Vol. 4(No. 2), 451-468. https://doi.org/http://doi.org/10.25273/citizenship.v4i2.1078.

Nafisah, D. (2016b). Peran Pendidikan Muatan Lokal Terhadap Pembangunan Karakter Bangsa. Citizenship Jurnal Pancasila Dan Kewarganegaraan, 4(2), 451. https://doi.org/10.25273/citizenship.v4i2.1078.

Puspitasari, F. B. \& Herdiati2, D. (2020). Pendidikan Karakter Melalui Lagu Di Sekolah Dasar. Jurnal Penelitian Musik, 1(2), 138-151. http://journal.unj.ac.id/unj/index.php/pm/article/view/16181.

Santika, I. W. E. (2020). Pendidikan Karakter pada Pembelajaran Daring. Indonesian Values and Character Education Journal, $\quad 3(1), \quad 8-19$. https://ejournal.undiksha.ac.id/index.php/IVCEJ/article/download/27830/15867.

Segoro, B., Sapto, A. \& Yuniastuti, Y. (2019). Buku Ajar Tematik Berbasis Muatan Lokal untuk Kelas IV Sekolah Dasar. Jurnal Pendidikan: Teori, Penelitian, Dan Pengembangan, 4(1), 1-5. https://doi.org/10.17977/jptpp.v4i1.11827.

Sulfahri. (2018). Peningkatan Hasil Belajar Mengapresiasi Karya Seni Rupa Melalui Penggunaan Media Pembelajaran Appreciation Card Pada Mahasiswa Semester VIA, Mata Kuliah Pendidikan Keterampilan Seni Rupa Program PGSD di Stkip Taman Siswa Bima Tahun 2017. Jurnal Pendidikan IPS, 8(1), 1-10. https://doi.org/https://doi.org/10.37630/jpi.v8i1.112.

Sundari, R., Karyono, T. \& Soeteja, Z. S. (2018). Pengembangan Buku Pengayaan Bermuatan Lokal Bagi Mahasiswa PGSD. Jurnal PGSD, 11(2), 100-105. https://doi.org/10.31602/muallimuna.v6i1.3334.

Syaifuddin, M. A. \& Fahyuni, E. F. (2019). Penguatan Pendidikan Karakter melalui Kurikulum Muatan Lokal di SMP Muhammadiyah 2 Taman. Palapa: Jurnal Studi Keislaman Dan Ilmu Pendidikan, 7(November), 267285. https://doi.org/10.36088/palapa.v7i2.358.

Torimtubun, H., Arifin, S. \& Yarnest. (2020). Analysis of the Influence of Character, Compensation and Teaching Experience on Teacher Professionalism in the Kepulauan Tanimbar Regency of Indonesia. International Journal of Advances in Scientific Research and Engineering, 06(08), 74-81. https://doi.org/10.31695/ijasre.2020.33863.

Utomo, C. B. \& Muntholib, A. (2018). Implementasi Pendidikan Karakter dalam Membentuk Sikap dan Perilaku Sosial Peserta Didik Melalui Pembelajaran Sejarah di SMA PGRI 1 Pati Tahun Pelajaran 2017/2018. Indonesian Journal of History Education, 6(1), 1-13. https://journal.unnes.ac.id/sju/index.php/ijhe/article/view/27332.

Wicaksono, M. A., Suhkabuden \& Husna, A. (2018). Pengembangan Media Pembelajaran yang Berupa Suplement pada Muatan Lokal Khas Ngawi. Journal Kajian Teknologi Pendidikan, 1(2), 1-8. http://journal2.um.ac.id/index.php/jktp/article/view/3716. 